\title{
sciendo
}

CIVIL AND ENVIRONMENTAL ENGINEERING REPORTS

E-ISSN 2450-8594

CEER 2019; 29 (1): 102-118

DOI: 10.2478/ceer-2019-0008

Original Research Article

\section{NATURAL GAS SAVING AND EMISSIONS DECREASE IN PUBLIC HEALTH CARE SECTOR - A CASE STUDY}

\author{
Otto MIERKA ${ }^{1}$, Miroslav VARINY ${ }^{1 *}$, Ingrida SKALÍKOVÁ ${ }^{2}$, Peter SÁMEL ${ }^{1}$, \\ Ján KIZEK ${ }^{3}$, Róbert $\mathrm{SUTHH}^{1}$, Karol NAGY ${ }^{1}$ \\ ${ }^{1}$ Slovak University of Technology, Department of Chemical and Biochemical \\ Engineering, Faculty of Chemical and Food Technology, Radlinského st 9, \\ 81237 Bratislava, Slovak Republic \\ ${ }^{2}$ Slovak University of Technology, Department of Building Services, Faculty of Civil \\ Engineering, Radlinského st 11, 81005 Bratislava, Slovak Republic \\ ${ }^{3}$ Technical University of Kosice, Department of Thermal Technology and Gas Industry, \\ Faculty of Metallurgy, Materials and Recycling, Letná st 9, 04200 Košice, \\ Slovak Republic
}

\begin{abstract}
A study on natural gas saving and emissions decrease in the public health care sector is presented. The analyzed hospital complex belongs to the largest ones in Slovakia and uses both hot water and water steam for heating purposes. Visual steam system inspection revealed serious inefficiencies, including steam venting, missing pipelines insulation and obsolete steam sources with dysfunctional blow-down system. Defined experiment with stepwise steam appliances shutdown enabled quantification of excess natural gas consumption due to these inefficiencies. Measures proposed for the solution of this state are inexpensive, with a short payback period. The expected natural gas savings amount up to $3200 \mathrm{MWh} /$ year, which represents roughly $50 \%$ of the total natural gas consumption in the hospital complex.
\end{abstract}

Keywords: public building, health care sector, natural gas, emissions, heat loss

* Corresponding author: Slovak University of Technology, Department of Chemical and Biochemical Engineering, Faculty of Chemical and Food Technology, Radlinského st 9, 81237 Bratislava, Slovak Republic, miroslav.variny@stuba.sk, tel. +421910966199 


\section{INTRODUCTION}

Energy consumption in the building sector amounts to between 20 to $40 \%$ of the total world energy consumption [1], [2]. The estimated energy saving potential in this sector is over $30 \%$ on average [3], which is often corroborated by related case studies and reviews [4] - [8]. However, the building retrofit rate is still very low, only about $3 \%$ in both USA and EU [9] and even lower is the new building construction rate, contributing together to only up to $5 \%$ incremental building energy efficiency investment in 2017 [2].

A brief examination of the current situation in case of the U.S.A. revealed that more than a half of the U.S. buildings will need extensive retrofits by 2050 to meet the goal to cut the energy use in buildings by half [10], [11]. This will require strong involvement of both government and municipalities to create further energy awareness programs, strengthen the role of buildings energy benchmarking and energy auditing and to overcome barriers to energy efficiency in this sector [12]. Implementation of smart metering and advanced energy saving systems will also aid in achieving this ambitious goal [6].

The 2010 Energy Performance of Buildings Directive [13] and the 2012 Energy Efficiency Directive [14] are the EU's main legislative instruments promoting improvement of the energy performance of buildings within EU providing a stable environment for investment decisions to be taken.

When the recast Directive was approved, many features of the original Directive were strengthened and new requirements were introduced; one of the most important is the final definition of nearly zero energy buildings (nZEB). General definition of a nearly zero energy building can be found in the work of Kurnitsky et al. [15].

The greatest potential for energy savings is in existing buildings, therefore they provide the greatest opportunity and challenge; no specific target has been set for their renovation [16]. However, Member States shall follow the lead of the public sector by developing policies and adopting measures (such as energy targets) to stimulate the transformation of refurbished buildings into very low energy buildings. Member States shall inform the Commission of their national plans [13]. The exact definition and the exact way of achieving this goal are left to the Member States. As presented in a recent report [17], many EU countries have difficulties to meet the expected 3\% per year buildings renovation rate that should satisfy the goals set by the Directive.

National definitions of nZEBs have been transposed to the Slovak legislation and supplemented by the Slovak national standards and regulations. Act No. 300/2012 [18] provides a definition of nZEB according to which they are buildings with very high energy performance. 
To achieve the nZEB parameters it is necessary to proceed from the acceptance and determination of three interrelated criteria:

- Reduction of specific heat demand for heating to minimum.

- Reduction of primary energy consumption for heating, cooling, ventilation, domestic hot water and lighting.

- Significant coverage of the overall primary demands by renewable energy sources [19], [20].

Energy demands are separated into five categories: heating, lighting, hot water, ventilation and total energy demand; providing scales of energy classes as a global indicator for different building types [21], [22]. The resulting energy performance indicator is called the "energy use". If the calculation methodology follows the rules of energy certification as defined in the Regulation 364/2012 Z.z. [23] and Regulation 324/2016 Z.z. [24], the heating system can be classified in one of the energy efficiency classes A to G. Tables 1 and 2 provide a numerical indicator classifying the energy use for heating and total energy use in selected types of buildings. The total energy use is calculated by a simple summation of the energy need and energy loss of heat emission and distribution systems.

Table 1 . Energy classes classifying the energy use for heating [23] in $\mathrm{kWh} / \mathrm{m}^{2} /$ year

\begin{tabular}{|c|c|c|c|c|c|c|c|}
\hline \multirow{2}{*}{ Building types } & \multicolumn{7}{|c|}{ Energy performance classes } \\
\cline { 2 - 8 } & $\mathrm{A}$ & $\mathrm{B}$ & $\mathrm{C}$ & $\mathrm{D}$ & $\mathrm{E}$ & $\mathrm{F}$ & $\mathrm{G}$ \\
\hline Office buildings & $\leq 28$ & $29-56$ & $57-84$ & $85-112$ & $113-140$ & $141-168$ & $>168$ \\
\hline Schools and educational facilities & $\leq 28$ & $29-56$ & $57-84$ & $85-112$ & $113-140$ & $141-168$ & $>168$ \\
\hline Hospitals & $\leq 35$ & $36-70$ & $71-105$ & $106-140$ & $141-175$ & $176-210$ & $>210$ \\
\hline Hotels and restaurants & $\leq 36$ & $37-71$ & $72-107$ & $108-142$ & $143-178$ & $219-213$ & $>213$ \\
\hline
\end{tabular}

Table 2. Total energy use [24] in $\mathrm{kWh} / \mathrm{m}^{2} /$ year

\begin{tabular}{|c|c|c|c|c|c|c|c|}
\hline \multirow{2}{*}{ Building types } & \multicolumn{7}{|c|}{ Energy performance classes } \\
\cline { 2 - 8 } & $\mathrm{A}$ & $\mathrm{B}$ & $\mathrm{C}$ & $\mathrm{D}$ & $\mathrm{E}$ & $\mathrm{F}$ & $\mathrm{G}$ \\
\hline Office buildings & $\leq 53$ & $64-125$ & $126-179$ & $180-232$ & $233-291$ & $292-350$ & $>350$ \\
\hline $\begin{array}{c}\text { Schools and } \\
\text { educational facilities }\end{array}$ & $\leq 43$ & $44-86$ & $87-125$ & $126-163$ & $164-204$ & $205-245$ & $>245$ \\
\hline Hospitals & $\leq 104$ & $105-207$ & $208-300$ & $301-393$ & $394-491$ & $492-590$ & $>590$ \\
\hline Hotels and restaurants & $\leq 94$ & $95-187$ & $188-275$ & $276-363$ & $364-454$ & $455-545$ & $>545$ \\
\hline
\end{tabular}

Slovakia has a huge potential in existing buildings renovation to achieve the nZEB standard even if it is not obligatory. Renovated buildings are required to meet the nZEB standard only if it is technically, functionally and economically feasible [23].

Of the total number of non-residential buildings, 15435 buildings were identified as owned by central and local government bodies between 1994 and 2003. Broken down by the built-up volume, $50.9 \%$ of these non-residential buildings were schools, $13.2 \%$ were healthcare facilities, $12.5 \%$ were administrative buildings 
and $10.3 \%$ were accommodation facilities [25]. The advanced average age of these buildings is documented in Fig. 1.

Health care buildings belong to the most intensive energy consumers within the public buildings group, exhibiting on average 200 to $350 \mathrm{kWh} / \mathrm{m}^{2} /$ year of the total energy consumption [29] - [29] which is over $60 \%$ higher than in other public buildings [30]. This is caused both by higher occupation compared to other public buildings as well as strict hygienic and microclimatic demands following the wellbeing of patients and personnel [28], [31].

Factors leading to such outcomes have been analyzed in detail in recent studies, including mathematical modelling and statistical analysis [27], [28], [31], providing relationships between individual factors and specific annual energy consumption.

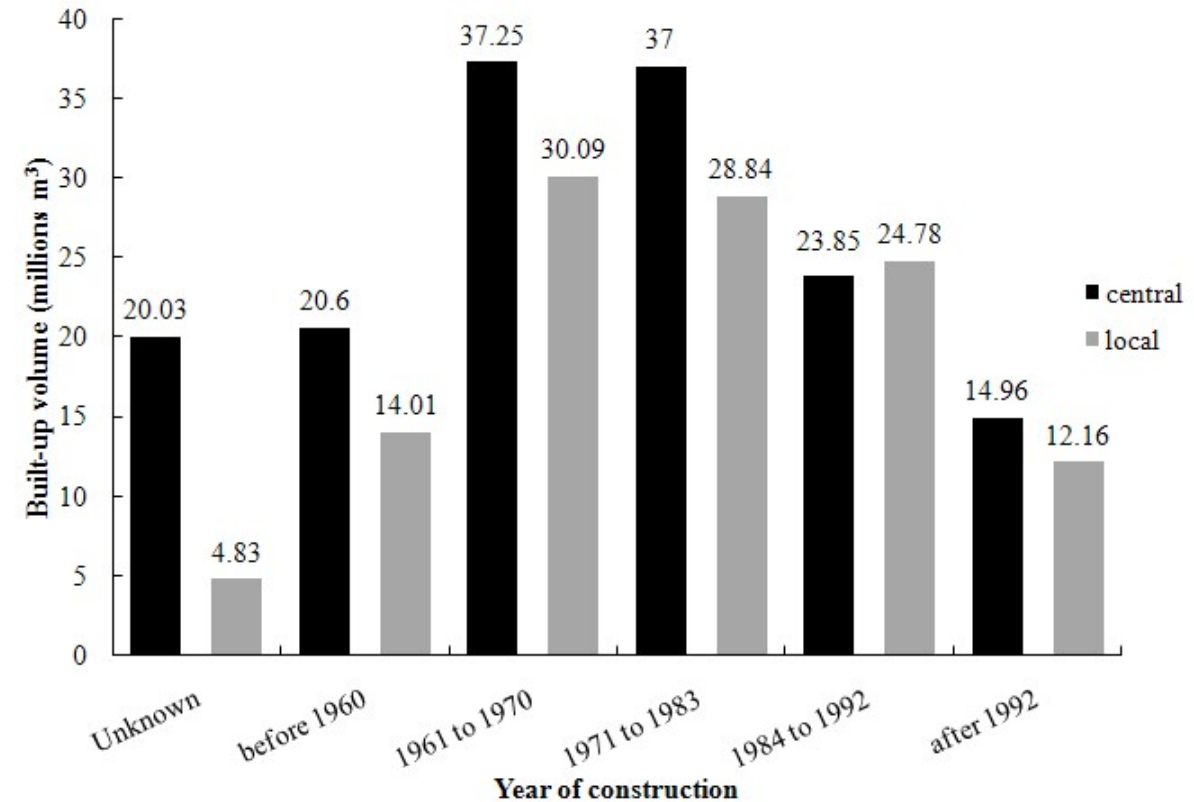

Fig. 1. Built-up volume of non-residential buildings owned by central (black) and local (grey) government bodies, by age [25]

Opportunities for energy consumption decrease in public health are tightly connected with the end use of energy in this sector. Nearly half of the energy consumption is typically consumed for building heating [20], [26], [32], followed by HVAC systems, lighting and other electric appliances. Thus, the majority of studies aimed at energy intensity decrease in this sector seek to lower the heating demands by proper building envelope retrofit, central heating unit upgrade, HVAC system modernization and regulation system improvement [4], [5], [33] [35]. The role of hospital personnel awareness of energy efficient behaviour is 
highlighted [36] - [37] with behavioural inertia being frequently identified as one of the barriers to substantial energy savings in this sector. A comprehensive analysis of all important barriers to energy efficiency in public health buildings is provided in [4], [5], [37], [38] where it is stated that the comparatively low priority of rational energy use in this sector is often overcome by other more urgent personnel activities and duties. Energy management introduction and energy performance contracting are seen as viable means towards energy savings [7], [39]. Parallel in-house activities aimed at personnel education have the potential to aid these processes [36]. Environmental effect of decreased energy consumption is dual: lower emissions released to cover the energy demand [26], [35] and improved working and living environment [40].

The advanced average age of Slovak hospitals (42 years, [41]) prompted the Slovak government to make a commitment to stepwise reconstruct and rehabilitate all large hospitals in Slovakia providing hundreds of millions euro to cover the associated financial expenses [42] - [45]. New hospital complexes are also to be built [41]. Investments to existing buildings are to be directed both to building envelopes modernization and new insulation as well as to internal equipment retrofit, including steam/hot water sources, HVAC units and chillers. In order to invest money into energy saving measures effectively, actual energy consumption has to be reviewed and non-investment options should be exploited to decrease the energy consumption which in turn should decrease the size and cost of the new equipment to be installed.

This study follows two goals:

1. Demonstrate the potential for low- or no-cost measures towards energy consumption decrease in the heat production and distribution system in a large hospital complex;

2. Provide a general methodology applicable to any hospital producing and consuming water steam to decrease the steam and heat losses by implementation of the best practice for steam and condensate systems applicable both for industrial and for residential systems [46], [47].

\section{MATERIALS AND METHODS}

\subsection{Hospital complex}

The hospital complex located in Bratislava belongs to the largest hospital complexes in Slovakia and serves for up to 700 thousand inhabitants of Bratislava city and adjacent regions. Heat delivery for its needs is ensured via two means: hot water for heating supplied from the municipal hot water network and steam production in natural gas fired steam boilers. Apart from the boiler room, natural gas is consumed in the kitchen for meals preparation. Table 3 shows the average 
annual consumption of energies in this complex. Considering the total hospital complex area of $77300 \mathrm{~m}^{2}$, the specific total energy consumption of nearly 250 $\mathrm{kWh} / \mathrm{m}^{2} /$ year is obtained which fits within the corresponding data span in hospitals worldwide [26] - [29].

Table 3. Average annual energy consumption in hospital

\begin{tabular}{|c|c|c|c||c|}
\hline Consumed energy & Hot water & Natural gas & Electric energy & Total \\
\hline Consumption (MWh/year) & 7860 & 6450 & 4870 & 19180 \\
\hline Share of total consumption (\%) & 41.0 & 33.6 & 25.4 & 100 \\
\hline
\end{tabular}

Unlike many other studies that strive to propose and implement measures for heat consumption reduction generally, this study is focused on the natural gas solely. Apart from a very small fraction used in the hospital kitchen it is almost exclusively used in gas fired steam boilers. Steam production, transport and consumption are traditional topic of industrial energy efficiency measures but receive less attention in the residential sphere. As it is obvious from Table 1, the natural gas share of the total energy consumption of the hospital is roughly $33 \%$ which makes it a promising candidate for consumption reduction. The authors intend to provide the readers with a comprehensive and easily to be followed methodology for steam system energy efficiency increase.

\subsection{Steam production, delivery and consumption}

The boiler room is equipped with three natural gas fired steam boilers. Boiler \#1 is the oldest one, with rated steam production capacity of $4 \mathrm{t} / \mathrm{h}$ but it is out of order. Boiler $\# 2$ is also of advanced age ( $>30$ years) with rated capacity of $6 \mathrm{t} / \mathrm{h}$ and is currently not in use. The newest boiler \#3 of rated capacity of $2 \mathrm{t} / \mathrm{h}$ steam is the only one that can be operated for longer periods of time. All boilers produce saturated $800 \mathrm{kPa}(\mathrm{g})$ steam that is throttled down to $300 \mathrm{kPa}(\mathrm{g})$, delivered to steam header and distributed to end users partly at this pressure and partly after pressure reduction to $70 \mathrm{kPa}(\mathrm{g})$. Schematic depiction of the steam production, delivery and consumption system is provided in Fig. 2.

Visual steam system inspection revealed the following defects that are often found in industrial steam systems as well [46], [47]:

- dysfunctional steam to deaerator delivery regulation system causing steam loss from the deaerator and lower water deaeration quality

- $\quad$ space heating in the boiler room was on

- excessive boiler blow-down leading to both water and heat losses

- boiler capacity was higher than system steam demand, which led to cyclical boiler operation and thus to lower boiler efficiency and higher breakdown probability 
- steam and condensate pipelines were ill insulated or the insulation was completely missing

- majority of the steam traps were oversized and/or dysfunctional, which led to steam leaks to condensate pipelines

- flash steam from the condensate collection tank was vented to the atmosphere without use.

Daily and hourly averages of natural gas consumption in the boiler room were analyzed and the results are presented in Chapter 3 in Fig. 3, 4 a, b. To assess the portion of steam lost or condensed due to ill insulated steam mains, the following procedure was devised:

- stepwise closing of the valves depicted in Fig. 2 interrupting thus steam delivery into individual steam consuming appliances

- quantification of natural gas consumption decrease in the boiler room associated with closing of individual valves using online data analysis of natural gas volumetric flow. Results of this procedure are shown in Fig. 5.

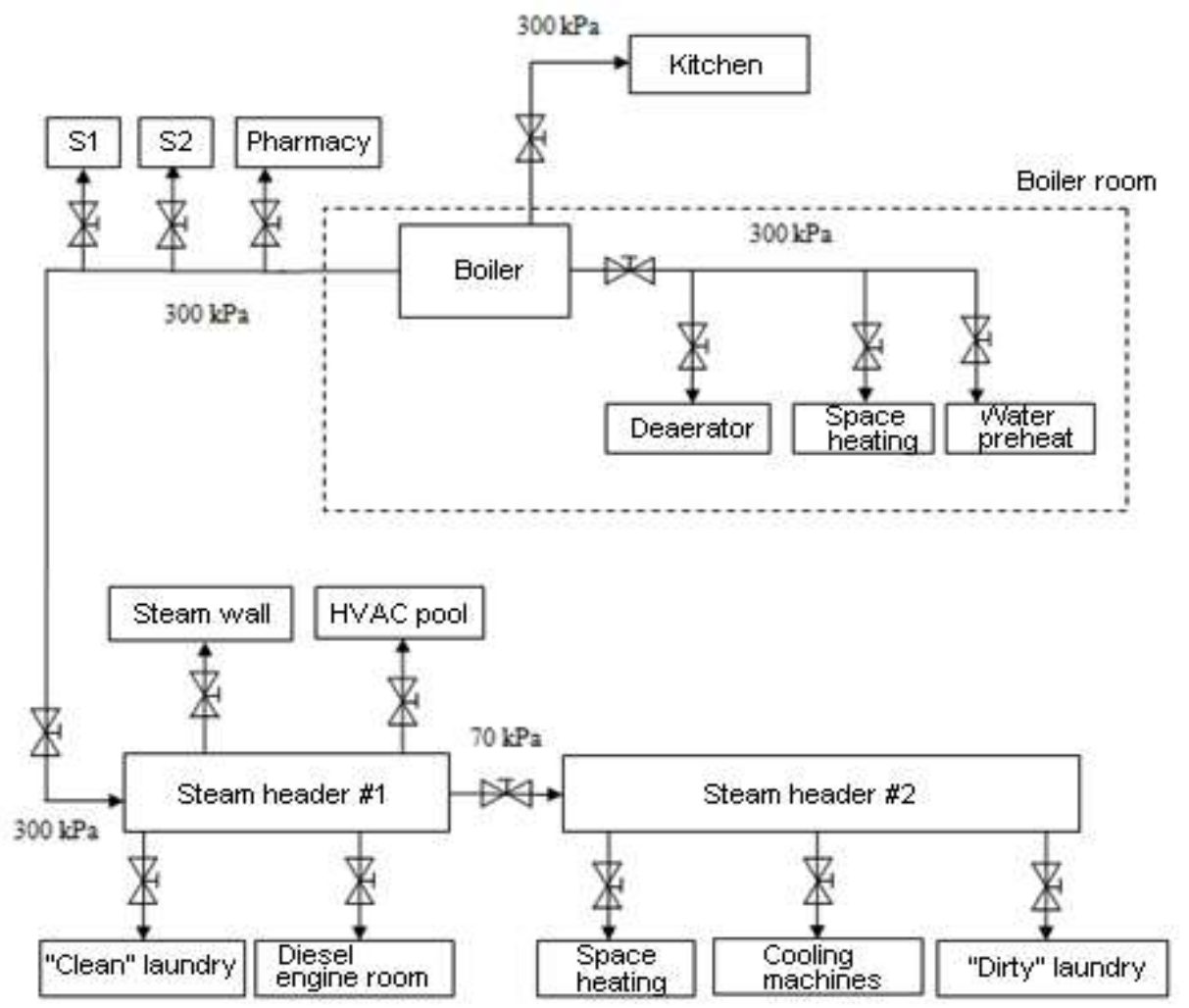

Fig. 2. Schematic depiction of the steam system. S1,2: Sterilizer units 
In order to ensure that no troubles arise from performing this experiment, it was carried out during evening and night. Appliances / systems with short allowable steam delivery interruption were shut down as the last ones. Ambient air temperature was $-15^{\circ} \mathrm{C}$ which meant that all space heaters and HVAC systems were in operation. Sterilizer units S1 and S2 operate batch-wise and were not in operation during the experiment.

\subsection{Environmental impact assessment}

Natural gas combustion produces lower emissions of harmful substances compared to other fossil fuels. Emission metering data for the hospital steam boilers were not available; thus the following data representing yearly averages for natural gas distributed in the Slovak Republic in 2018 [48] were applied:

- natural gas $\mathrm{CO}_{2}$ emission factor of $55.9 \mathrm{t} / \mathrm{TJ}$

- natural gas volumetric higher heating value of $10.74 \mathrm{kWh} / \mathrm{m}^{3}$ (at $15^{\circ} \mathrm{C}$ and $101.325 \mathrm{kPa}$ ).

The representative value of nitrogen oxides emissions from natural gas fired boilers of $65.3 \mathrm{~kg} / \mathrm{TJ}$ were used [49] yielding the following figures of volumetric emission factors for natural gas combustion in steam boilers:

- $\mathrm{CO}_{2}: 2162 \mathrm{~kg} / 1000 \mathrm{~m}^{3}$

- $\mathrm{NO}_{\mathrm{x}}: 2.52 \mathrm{~kg} / 1000 \mathrm{~m}^{3}$.

Considering the advanced age of the hospital boilers, these values represent the lower limit and can be used as conservative estimates for environmental impact assessment of potential natural gas consumption reduction. Emission reduction, $R$, of individual gases was estimated from Eq. (2.1) and (2.2),

$$
\begin{gathered}
R_{C O}(\mathrm{~kg} / \text { year })=R_{N G}\left(\mathrm{~m}^{3} / \mathrm{h}\right) .2 .16 \mathrm{~kg} / \mathrm{m}^{3} .8760 \mathrm{~h} / \text { year } \\
R_{N O x}(\mathrm{~kg} / \text { year })=R_{N G}\left(\mathrm{~m}^{3} / \mathrm{h}\right) \cdot \frac{2.52 \mathrm{~kg}}{1000 \mathrm{~m}^{3}} .8760 \mathrm{~h} / \text { year }
\end{gathered}
$$

where $R_{N G}$ denotes the average potential natural gas savings quantified in Chapter 3 and $8760 \mathrm{~h} /$ year is the system operational time.

\section{RESULTS AND DISCUSSION}

Fig. 3 provides an overview of daily natural gas consumptions in 2018. It can be seen that the lowest natural gas consumption was roughly $50 \%$ of the highest one. Such natural gas consumption trend is applicable to a continuous heat demanding production process in the industrial sphere. 
This, however, is not the case here. As it appears from Fig. 2, steam consumers are operated either cyclically regardless of the season (Sterilizers, Laundry) or during the heating season only. Hot tap water is produced using the hot water from the municipal hot water system and thus it does not contribute to the rather high natural gas consumption in summer. Occasional natural gas consumption increase highlighted in Fig. 3 results from short periods of municipal hot water supply unavailability when steam is used in certain HVAC / space heating units instead of hot water.

Analysis of hourly natural gas consumption provided in Fig. 4 a, b enables better insight into this matter. Peak and off peak periods associated with morning and evening/night hours respectively can clearly be recognized. They can be attributed to steam consuming appliances that are in operation in the morning and afternoon hours, such as Sterilizers and Laundry with relative peak height of around $20 \mathrm{~m}^{3} / \mathrm{h}$ of natural gas consumption.

Basic natural gas consumption is between 40 and $50 \mathrm{~m}^{3} / \mathrm{h}$ in summer and 60 to $110 \mathrm{~m}^{3} / \mathrm{h}$ in winter obviously depending on the temperature outside. There is almost no steam consumption during summer nights, thus it was anticipated that up to $40 \mathrm{~m}^{3} / \mathrm{h}$ of natural gas are consumed to cover heat and steam losses from the system. The experiment as described in Chapter 2.2 provided proof of this assumption and allowed quantifying the excess natural gas consumption.

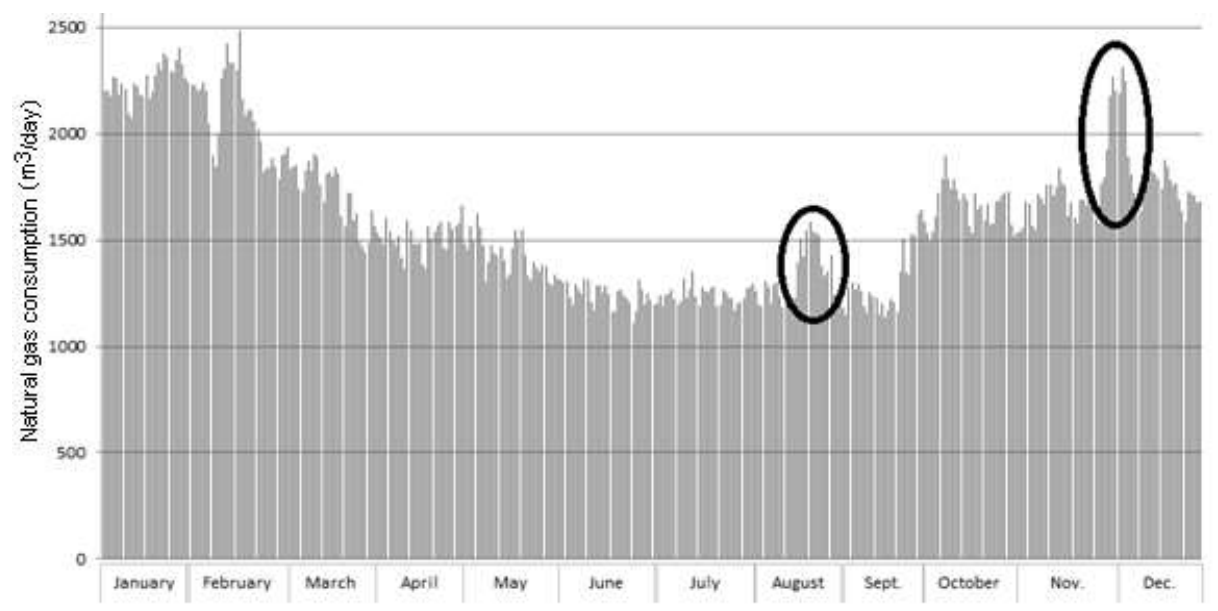

Fig. 3. Overview of daily natural gas consumption in the boiler room in 2018 


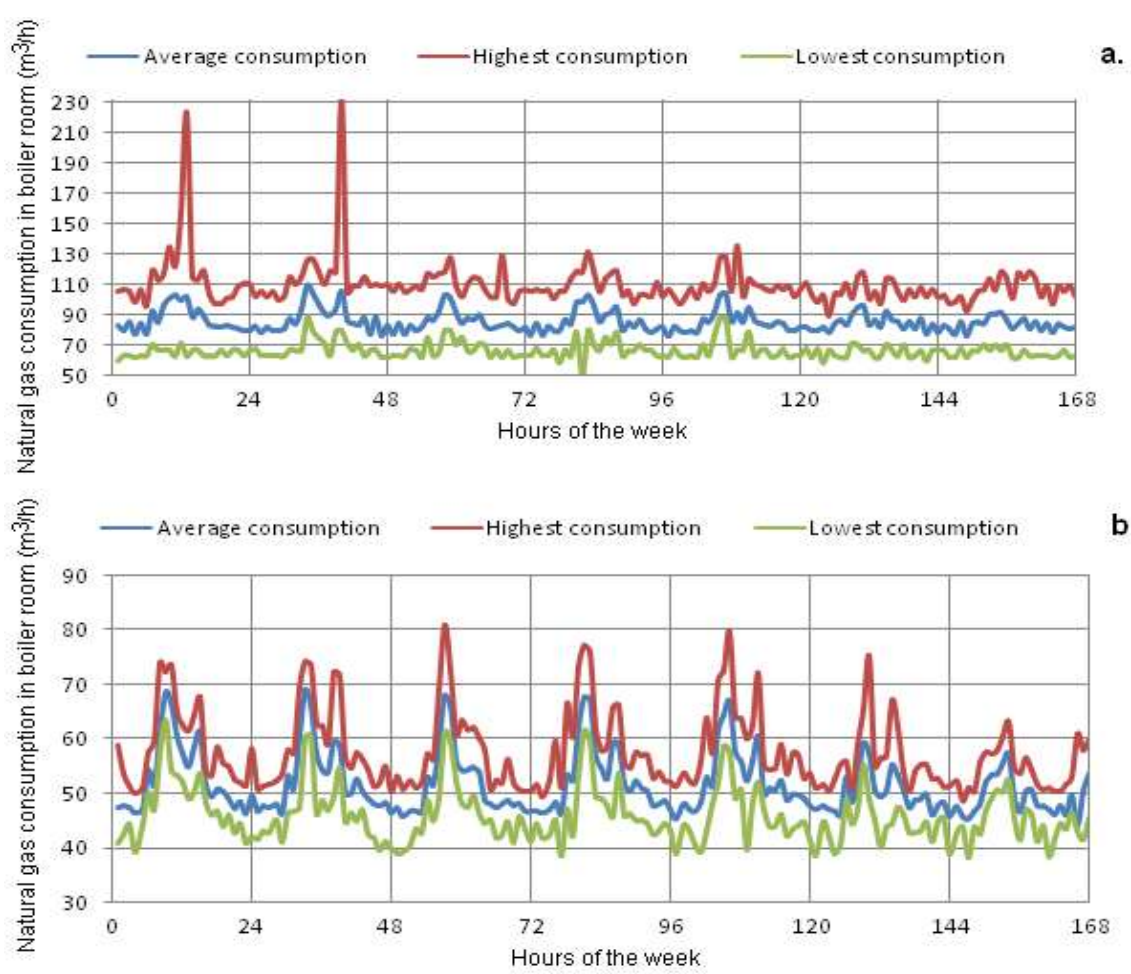

Fig. 4 a, b. Analysis of typical hourly natural gas consumption in the boiler room in 2018: a. in winter and b. in summer

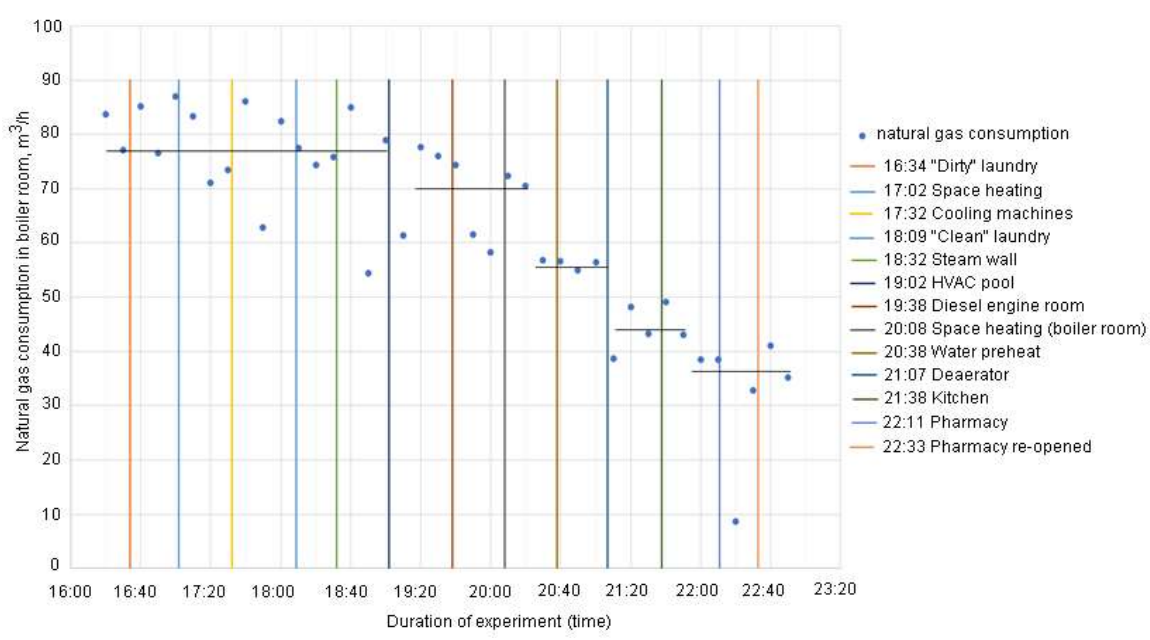

Fig. 5. Gradual natural gas consumption reduction during the experiment. Natural gas volumetric flow is recalculated to $15^{\circ} \mathrm{C}$ and $101.325 \mathrm{kPa}$ 
Natural gas consumption trend during the experiment is shown in Fig. 5. It can be seen that natural gas consumption did not change substantially after closing all steam pipelines supplying the $70 \mathrm{kPa}$ (g) steam to individual appliances. It could thus be concluded that steam and heat losses corresponding to the $70 \mathrm{kPa}(\mathrm{g})$ steam system are insignificant. Natural gas consumption decreased gradually after closing further steam valves to the final value of around $35 \mathrm{~m}^{3} / \mathrm{h}$ which represents the excess steam consumption used to cover steam and heat losses from the steam system only.

Furthermore, a $10 \mathrm{~m}^{3} / \mathrm{h}$ natural gas consumption difference was observed after shutting down the deaerator steam supply. With properly working steam supply regulation this should not result in visible natural gas consumption decrease. In this particular case, the $10 \mathrm{~m}^{3} / \mathrm{h}$ natural gas consumption decrease corresponded to steam vented from the deaerator when no cold water was supplied. It has to be stressed that the deaerator system, like the rest of the steam system, is fairly oversized and thus the cold water supply pump operates cyclically. With the deaeration steam supply malfunction, steam is consumed usefully only during cold water pumping; after the water in the deaerator is heated to the deaeration temperature, excess steam is vented into the atmosphere.

Based on the visual inspection and experiment results, the following measures for natural gas consumption reduction were recommended:

1. Installation of a functional deaeration steam regulation system able to save up to $10 \mathrm{~m}^{3} / \mathrm{h}$ of natural gas;

2. Application of new insulation on steam and condensate pipelines, replacement of dysfunctional steam traps with new ones and regular monitoring of their performance;

3. Switching off space heating in the boiler room;

4. Repairing the currently dysfunctional boiler water conductivity measurement and reduce boiler blow-down.

All these measures require only moderate investment and exhibit both to our experience and according to literature [47], [48] a short pay-back period ranging from several months (regulation valve replacement, blow down reduction) up to one to two years (new insulation, new steam traps). By combination of all measures together, at least $35 \mathrm{~m}^{3} / \mathrm{h}$ of natural gas can be saved, which represents the yearly energy saving potential of $3200 \mathrm{MWh}$ or roughly $50 \%$ of the total natural gas consumption in the hospital. Considering an average household with the annual natural gas consumption of $1500 \mathrm{~m}^{3} /$ year, the expected 3200 $\mathrm{MWh} /$ year natural gas saving is equivalent to ca. 200 households.

Applying equations (2.1) and (2.2), the related emissions decrease can be estimated to amount to 644 ton of $\mathrm{CO}_{2}$ and 0.75 ton of $\mathrm{NO}_{\mathrm{x}}$. 


\section{CONCLUSIONS}

Public health sector worldwide has the potential for substantial energy intensity decrease that still remains largely untouched. As documented in this study, energy consumption cuts up to several tens \% are possible with simple and easily applicable measures. The methodology for achievable savings estimation is readily transferable to other hospital complexes or any other public buildings employing steam systems. It should be incorporated into energy management systems in the public health sector as a simple and reliable means of steam system defects identification and quantification. Thereby, the public building sector energy efficiency can be improved and the ambitious carbon emission cut goals of the EU should be approached.

\section{ADDITIONAL INFORMATION}

This work was financially supported by the Slovak Scientific Agency, Grants No. VEGA 1/0659/18 and No. VEGA 1/0847/18; by the Ministry of Education, Science, Research and Sport of the Slovak Republic under KEGA Grant 044STU4/2018 and by the Slovak Research and Development Agency, Grant No. APVV15-0148. The authors also gratefully acknowledge the support from the project Science and Technology Park STU Grant no. ITMS26240220084, co-financed by the European Regional Development Fund.

\section{REFERENCES}

1. International Energy Agency (IEA) 2011. International energy outlook.

2. United Nations Environment Programme 2018. Global status report 2018. [31.01.2019]. Available from https://www.unenvironment.org/resources/report/global-status-report-2018.

3. International Energy Agency (IEA) 2012. World energy outlook 2012.

4. Bertone, E, Stewart, RA, Sahin, O, Alam, M, Zou, PXW, Buntine, Ch and Marshall, C 2018. Guidelines, barriers and strategies for energy and water retrofits of public buildings. Journal of Cleaner Production 174, 1064-1078.

5. Bertone, E, Sahin, O, Stewart, RA, Zou, P, Alam, M and Blair, E 2016. Stateof-the-art review revealing a roadmap for public building water and energy efficiency retrofit projects. International Journal of Sustainable Built Environment 5, 526-548.

6. Fernandez, N, Katimapula, S, Wang, W, Xie, Y and Zhao, M 2018. Energy savings potential from improved building controls for the US commercial building sector. Energy Efficiency 11, 393-413. 
7. Principi, P, Fioretti, R, Carbonari, A and Lemma, M 2016. Evaluation of energy conservation opportunities through Energy Performance Contracting: A case study in Italy. Energy and Buildings 128, 886-899.

8. Oree, V, Khoodaruth, A and Teemul, H 2016: A case study for the evaluation of realistic energy retrofit strategies for public office buildings in the Southern Hemisphere. Building Simulation 9, 113-125.

9. Zhivov, A 2013. Energy Efficient Retrofit of Government/Public Buildings Annex 46 (completed) and Annex 61 (new). IEA ECB Program Executive Committee Meeting, Technical Day, Rome.

10. Sebi, C, Nadel, S, Schlomann, B and Steinbach, J 2019. Policy strategies for achieving large long-term savings from retrofitting existing buildings. Energy Efficiency 12, 89-105.

11. Nadel, S 2016. Pathway to cutting U.S. energy use and carbon emissions in half. Washington: ACEEE. [04.02.2019]. Available from http://aceee.org/white-paper/pathways-cutting-energy-use.

12. Palmer, $K$ and Walls, M 2017. Using information to close the energy efficiency gap: a review on benchmarking and disclosure ordinances. Energy Efficiency 10, 673-691.

13. Directive 2010/31/EU of the European Parliament and of the Council of 19 May 2010 on the energy performance of buildings.

14. Directive 2012/27/EU of the European Parliament and of the Council of 25 October 2012 on energy efficiency.

15. Kurnitski, J, Allard, F, Braham, D, Goeders, G, Heiselberg, P, Jagemar, L, Kosonen, R, Lebrun, J, Mazzarella, L, Railio, J, Seppänen, O, Schmidt, M and Virta, M 2011. How to define nearly net zero energy buildings nZEB REHVA proposal for uniformed national implementation of EPBD recast. The REHVA European HVAC Journal 48, 6-12.

16. Magyar, Z 2011. Buildings in the key role in the EU Energy Efficiency Action Plan. The REHVA European HVAC Journal 48, 86-88.

17. EUROSAI WGEA Cooperative Audit 2018. Energy Efficiency for Public Sector Buildings. Final draft for approval. [12.02.2019]. Available from https://www.nku.gov.sk/documents/10272/1267669/2018++Energy+efficien cy+in+ public+buildings/61433f69-645a-478c-93e96a808e344642? version $=1$.1\&previewFileIndex $=$.

18. Act. No. 300/2012 Z. z. on the buildings energy efficiency, amendment of act No. 555/2005. [12.02.2019]. Available from https://www.noveaspi.sk/products/lawText/1/78303/1/2 (In Slovak).

19. Krajčík, M and Petráš, D 2015. Energetické hodnotenie budov, Nakladatel'stvo STU. Bratislava, Slovak Republic. 
20. Petráš, D, Krajčík, M, Bugáň, J and Ďurišová, E 2014. Indoor environment and energy performance of office buildings with a low temperature heating / high temperature cooling system. Advanced Materials Research 899, 36-41.

21. Dahlsveen, T, Petráš, D, Chmúrny, I, Smola, A, Lulkovičová, O, Füri, B and Konkol', R 2008. Energetický audit a certifikácia budov. Jaga group, Bratislava, Slovak Republic.

22. Babiak, J, Olesen, BW and Petráš, D 2007. Low temperature heating and high temperature cooling. Rehva Guidebook 7, Rehva, Brussels, Belgium.

23. Regulation of the Ministry of Transport. Construction and Regional Development 364/2012 Z.z. [12.02.2019]. Available from

https://www.mindop.sk/ministerstvo-1/vystavba-

5/stavebnictvo/legislativa/vyhlaska-ministerstva-dopravy-vystavby-aregionalneho-rozvoja-slovenskej-republiky-c-324-2016-ktorou-sa-meni-adoplna-vyhlaska-ministerstva-dopravy-vystavby-a-regionalneho-rozvojaslovenskej-republiky-c-364-2012-z-z-ktorou-sa-vykonava-zakon-c (In Slovak).

24. Regulation of the Ministry of Transport. Construction and Regional Development 324/2016 Z.z. [11.02.2019]. Available from https://www.mindop.sk/ministerstvo-1/vystavba5/stavebnictvo/legislativa/vyhlaska-ministerstva-dopravy-vystavby-aregionalneho-rozvoja-slovenskej-republiky-c-324-2016-ktorou-sa-meni-adoplna-vyhlaska-ministerstva-dopravy-vystavby-a-regionalneho-rozvojaslovenskej-republiky-c-364-2012-z-z-ktorou-sa-vykonava-zakon-c (In Slovak)

25. Slovak Report for the Commission (EU) 2013. Reference Buildings. Determination of Cost-optimal Levels of Minimum Energy Performance Requirements. [11.02.2019]. Available from www.ec.europe.eu.

26. Jiang, Ch, Xing, J, Ling, J and Qui, X 2012. Energy consumption and carbon emissions of hospitals in Tianjin. Frontiers in Energy 6, 427-435.

27. Puente-Gil, Á, González-Martínez, A, Borge-Diez, D, Martínez-Cabero, MÁ and de Simón-Martín, M 2019. True power consumption labeling and mapping of the health system of the Castillia y León region in Spain by clustering techniques. Energy Procedia 157, 1164-1181.

28. González, AG, García-Sanz-Calcedo, J and Salgado, DR 2018. A quantitative analysis of final energy consumption in hospitals in Spain. Sustainable Cities and Society 36, 169-175.

29. Gao, Z, Li, Y and Ning, Y 2017. The survey and analysis on the energy consumption of hospital buildings in Shandong province. Procedia Engineering 205, 2485-2492. 
30. Čongradac, V, Prebiračević, B, Jorgovanović, N and Stanišić, N 2012. Assessing the energy consumption for heating and cooling in hospitals. Energy and Buildings 48, 146-154.

31. González-Gil, A, López-González, JL, Fernández, M, Eguía, P, Erkoreka, A and Granada, E 2018. Thermal energy demand and potential energy savings in a Spanish surgical suite through calibrated simulations. Energy and Buildings 174, 513-526.

32. Centre for Analysis and Dissemination of Demonstrated Energy Technologies (CADDET) 1997. Saving energy with energy efficiency in hospitals. [07.02.2019]. Available from https://www.certh.gr/dat/834E8024/file.pdf.

33. Buonomano, A, Calise, F, Ferruzzi, G and Palombo, A 2014. Dynamic energy performance analysis: Case study for energy efficiency retrofits of hospital buildings. Energy 78, 555-572.

34. Ascione, F, Bianco, N, De Masi, RF and Vanoli, GP 2013. Rehabilitation of the building envelope of hospitals: Achievable energy savings and microclimatic control on varying the HVAC systems in Mediterranean climates. Energy and Buildings 60, 125-138.

35. Teke, A and Timur, O 2014. Assessing the energy efficiency improvement potentials of HVAC systems considering economic and environmental aspects at the hospitals. Renewable and Sustainable Energy Reviews 33, 224235.

36. Morgenstern, P, Raslan, R and Huebner, G 2016. Applicability, potential and limitations of staff-centred energy conservation initiatives in English hospitals. Energy Efficiency 9, 27-48.

37. Bakaimis, B and Papanikolaou, I 2017. Electrical energy saving policies, initiatives, results, challenges and lessons learned from Grevena hospital. Procedia Environmental Sciences 38, 882-889.

38. Wang, T, Li, X, Liao, P-Ch and Fang, D 2016. Building energy efficiency for public hospitals and healthcare facilities in China: Barriers and drivers. Energy 103, 588-597.

39. Lee, D and Cheng, Ch-Ch 2016. Energy savings by energy management systems: A review. Renewable and Sustainable Energy Reviews 56, 760-777.

40. Evens, A, Garascia, M and Isaacson, M 2017. Utilities and health: Energy efficiency as a common link. The Electricity Journal 30, 10-14.

41. Document from government session Nr. 118/2018. National investment plan of the Slovak Republic for the years 2018-2030. Pilot version, approved 12.09.2018. [06.02.2019]. Available from http://www.rokovania.sk/File.aspx/ViewDocumentHtml/Mater-Dokum220226? prefixFile $=m_{-}$(In Slovak). 
42. Government office the Slovak Republic. Press report 2018. Premiér: Ohlásil masivne investície do slovenských nemocnic. [04.02.2019]. Available from https://www.vlada.gov.sk//premier-ohlasil-masivne-investicie-doslovenskych-nemocnic/ (In Slovak).

43. Government office the Slovak Republic. Press report 2018. Peter Pellegrini: Prichádzajú najväčšie investície do našich nemocníc v histórii Slovenska. [04.02.2019]. Available from https://www.vlada.gov.sk//peter-pellegriniprichadzaju-najvacsie-investicie-do-nasich-nemocnic-v-historii-slovenska/ (In Slovak).

44. Government office the Slovak Republic. Press report 2018. Premiér: Je dôležité, aby sme urobili všetko pre komfort slovenského pacienta. [04.02.2019]. Available from https://www.vlada.gov.sk//premier-je-doleziteaby-sme-urobili-vsetko-pre-komfort-slovenskeho-pacienta/ (In Slovak).

45. Government office the Slovak Republic. Press report 2019. A. Kalavská: Rekonštrukcia nemocnice v B. Bystrici sa začne koncom roka. [04.02.2019]. Available from https://www.vlada.gov.sk//a-kalavska-rekonstrukcianemocnice-v-b-bystrici-sa-zacne-koncom-roka/ (In Slovak).

46. Einstein, D, Worrell, E and Khrushch, M 2001. Steam Systems in Industry: Energy Use and Energy Efficiency Improvement Potentials. [29.01.2019]. Available from https://www.osti.gov/scitech/servlets/purl/789187>.

47. Spirax-Sarco 2011. The steam and condensate loop. Effective steam engineering for today. Spirax-Sarco Limited, Cheltenham, UK.

48. SPP, a.s. the major natural gas distributor in Slovak Republic 2018. Natural gas composition, heating value and emission factor in 2018. [05.02.2019]. Available from https://www.spp.sk/sk/velki-zakaznici/zemny-plyn/ozemnom-plyne/emisie/ (In Slovak).

49. Šoltés, J 2011. Environmental aspects of an energy audit. Národná energetická spoločnost'. [05.02.2019]. Available from https://www.siea.sk/materials/files/poradenstvo/aktuality/2012/konferencia ea_ii/prednasky/3_Soltes_Environmentalne_aspekty_auditu.pdf (In Slovak).

\section{OGRANICZENIE ZUŻYCIA GAZU ZIEMNEGO I REDUKCJA EMISJI W SEKTORZE ZDROWIA PUBLICZNEGO - STUDIUM PRZYPADKU}

$$
\text { Streszczenie }
$$

Niniejszy artykuł prezentuje studium przypadku na temat ograniczenia zużycia gazu ziemnego i emisji w sektorze zdrowia publicznego. Analizowany kompleks szpitalny należy do największych na Słowacji i używa do ogrzewania zarówno ciepłej wody użytkowej, jak i pary wodnej. Kompleks ten będzie w najbliższych latach poddany 
renowacji, włącznie $\mathrm{z}$ instalacją dystrybucji mediów. Analiza obecnego systemu I wynikające $\mathrm{z}$ niej zaproponowane sposoby na zaoszczędzenie energii oferują redukcję kosztów powiązanych z przyszłą inwestycją. Wizualna ocena systemu dystrybucji pary wodnej ujawniła poważne wady tego systemu, w tym w odpowietrzaniu systemu, uszkodzonej bądź brakującej izolacji rur, przestarzałych bojlerach parowych $\mathrm{z}$ niedziałającym systemem usuwania zanieczyszczeń. Eksperyment ze stopniowym wyłączaniem urządzeń parowych umożliwił ilościowe określenie nadmiaru zużycia gazu ziemnego spowodowanego wspomnianymi niedostatkami. Metodologia takiego eksperymentu jest uniwersalna i łatwa w zastosowaniu w jakimkolwiek innym budynku użyteczności publicznej gdzie podobny system pary wodnej jest w użyciu. Zaproponowane rozwiązania dla poprawy takiego stanu są niedrogie i z krótkim czasem zwrotu inwestycji. Zastosowanie nowej izolacji rur, naprawa odwadniaczy oraz naprawa zaworów redukcyjno-regulacyjnych do odpowietrzania pary w odpowietrznikach są przedmiotem rozważań. Oczekiwana redukcja zużycia gazu ziemnego wynosi do 3200 $\mathrm{MWh} /$ rok, co stanowi około $50 \%$ rocznego zapotrzebowania tego gazu w kompleksie szpitalnym. Ocena środowiskowa zaproponowanych zmian pozwala oczekiwać redukcji emisji dwutlenku węgla na poziomie 644 ton rocznie oraz tlenków azotu na poziomie 0.75 ton rocznie.

Słowa kluczowe: budynek użyteczności publicznej, gaz ziemny, emisja, straty ciepła

Editor received the manuscript: 20.02.2019 